\title{
Epidemiologic profile of salivary gland neoplasms: analysis of 245 cases
}

\author{
Solange Souza Lima', Andréa Ferreira Soares', \\ Rivadávio Fernandes Batista de Amorim ${ }^{3}$, \\ Roseana de Almeida Freitas ${ }^{4}$
} Key words: epidemiology, mouth neoplasms,
salivary gland diseases.

\section{Summary}

\begin{abstract}
A
im: The aim of the present study is to establish the relative frequency and distribution of benign and malignant epithelial neoplasms of salivary glands in the Pathology and Cytology Laboratory, Study design: Historic cohort. Material and method: in the state of Sergipe, during the period 1980-1999. The neoplasms were individualized by gender, age, race of the patients, anatomic localization of the lesions and histopathological diagnosis. Results: Out of 162,312 registered cases, 245 were salivary gland epithelial neoplasms and 187 (76.33\%) were benign and 58 (23.67\%) were malignant. Pleomorphic adenoma was the most frequent benign neoplasm (89.94\%) and adenoid cystic carcinoma represented the most prevalent malignant neoplasm (22.41\%). The benign neoplasms occurred mainly between the second and third decades of life and showed preference for female, while malignant neoplasms were diagnosed between the sixth and seventh decades of life and in women. Conclusion: The data demonstrated that epidemiology profile of the studied neoplasms corroborated most of the studied literature.
\end{abstract}

${ }^{1}$ Master in Oral Pathology, Program of Post-graduation in Oral Pathology, UFRN.
${ }^{2}$ Ph.D. studies in Oral Pathology under course, Program of Post-graduation in Oral Pathology, UFRN.
${ }^{3}$ Ph.D. in Oral Pathology under course, Program of Post-graduation in Oral Pathology, UFRN.
${ }^{4}$ Professor, Ph.D., Program of Post-graduation in Oral Pathology, UFRN.
Affiliation: Federal University of Rio Grande do Norte, UFRN. Natal/ RN, Brazil. Support: Coordenação de Aperfeiçoamento de Pessoal de Nível Superior - CAPES (Brazil).

Address correspondence to: Dra. Roseana de Almeida Freitas - Programa de Pós-Graduação em Patologia Oral, Departamento de

Odontologia, Universidade Federal do Rio Grande do Norte - Av Senador Salgado Filho 1787 Lagoa Nova Natal RN 59056-000.

website: www.patologiaoral.com.br - E-mail: roseana@patologiaoral.com.br

Article submited on October 11, 2005. Article accepted on May 05, 2005. 


\section{INTRODUCTION}

Concerning head and neck regions, it is known that tumors of the salivary glands correspond, on average, to 3\% of the affections on this site, the majority being of epithelial origin $^{1,2}$. They present varied etiology and several risk factors have been identified so far, although lack of information from medical records and clinical files minimize the importance of these tumors in the tumorigenesis of salivary glands ${ }^{3}$.

According to literature, salivary gland tumors are probably the most complex among human neoplasias, due to their broad histological spectrum resulting from a multiple tumor-cell differentiation, its cell arrangements and extracellular matrix synthesis produced by certain tumor cells ${ }^{4}$.

Benign tumors are the most frequent types, corresponding to $54-79 \%$ of these diseases, while malignant tumors account for $21-46 \%$ of tumors $3,5,6$.

Based on these studies, pleomorphic adenoma is the most common salivary gland tumor, once it accounts for nearly $50 \%$ of all neoplasms occurring at this anatomical site. The second most frequent condition is Warthin's tumor, also called papillary lymphomatous cystadenoma, corresponding to $4-14 \%$ of all tumors. Regarding malignant entities, the mucoepidermoid carcinoma, the cystic adenoid carcinoma and ex adenoma pleomorphic carcinoma are very frequently found ${ }^{7,8}$. The clinical course of such neoplasias is generally characterized by insidious growth and inoffensive feature. However, indication of malignancy may be present, such as pain and paralysis of the cranial nerve ${ }^{9,10}$.

Relevant series published in literature showed that salivary neoplasms, either benign or malignant, are usually present in greater salivary glands, specially the parotid (64$80 \%)$. When they affect minor salivary glands, the palate is the most affected site. Relative to gender, it was verified that, generally, both benign and malignant types were more prevalent in women. Peak incidence relative to age showed variations, with concentrations at the third decade of life for benign tumors and the sixth decade for malignant tumors. Regarding race, there was little relevance due to lack of information from the sources investigated ${ }^{7,11,12}$.

Therefore, the aim of this study was to carry out an epidemiological survey of benign and malignant cases of major and minor salivary glands, recorded at the laboratory of Pathology and Cytology Ltd., in Aracaju/SE in the period of 1980 and 1999.

\section{MATERIAL AND METHODS}

\section{Sample}

The sample consisted of 245 cases of major and minor salivary glandular epithelial neoplasias selected among 162,312 cases recorded in the files of the Laboratory of
Pathology and Cytology Ltd. in Aracaju/SE in the period of January 1980 and December 1999.

\section{Procedures and Material Collection}

Data collection was based on continuous information obtained with the sample's results of histopathology exams, which were reproduced to a standard file developed specifically for this analysis. Patents' age, gender and race, as well as anatomical site and histopathological diagnosis of lesion were the analyzed variables.

Among the histopathological results obtained in the files, all cases that did not fit the second edition of World Health Organization classification (1991) were revised and reclassified.

\section{RESULTS}

All 245 cases of salivary epithelial neoplasia corresponded to $0.15 \%$ of the total cases registered by this laboratory during the stated period. Benign neoplasias were more common than malignant ones, while pleomorphic adenoma was the most frequent type (Table 1). Regarding malignant neoplasias, cystic adenoid carcinoma followed by acinar-cell carcinoma and mucoepidermoid carcinoma were the most frequently observed types (Table 1). Considering the anatomical site, greater salivary glands, specially the parotid gland (Tables 2 and 3), were the most affected both by benign and malignant neoplasias.

Concerning patients' gender, women were more frequently affected (Tables 4 and 5). Peak incidence relative to age was the third and seventh decades for benign and malignant neoplasias (Tables 6 and 7), respectively. Finally, a higher incidence was observed among Caucasians (Tables 8 and 9).

\section{DISCUSSION}

Altered salivary glandular tissue may produce such diversified histopathological expressions that the development of a universal classification accepted by researchers is very hard, especially when diagnosing certain neoplasias. Multiple histological aspects of salivary glandular neoplasias have been attributed to presence of myoepithelial cells in these glands ${ }^{3}$. There were several attempts to classify these lesions in the past years, and the most recent and adopted classification is the World Health Organization publication (1991). It is clear that this document aims at grouping all known salivary glandular neoplasias into two major groups: benign and malignant. Once this classification was developed by an institution accepted and recognized worldwide, the present study followed their criteria. 
Table 1. Distribution of benign and malignant neoplasias according to histological type. Aracaju/SE, 2004.

\begin{tabular}{|c|c|c|}
\hline \multirow[t]{2}{*}{ Histological Type } & \multicolumn{2}{|c|}{ Total } \\
\hline & Number(n) & Percentage(\%) \\
\hline Pleomorphic Carcinoma & 168 & 68.57 \\
\hline Warthin's Tumor & 17 & 6.94 \\
\hline Canalicular Adenoma & 2 & 0.82 \\
\hline Cystic Adenoid Carcinoma & 13 & 5.31 \\
\hline Acinar-cell Carcinoma & 12 & 4.90 \\
\hline Mucoepidermoid Carcinoma & 11 & 4.49 \\
\hline Carcinoma in Pleomorphic Adenoma & 9 & 3.67 \\
\hline Adenocarcinoma & 9 & 3.67 \\
\hline Squamous-cell Carcinoma & 2 & 0.82 \\
\hline Salivary Duct Carcinoma & 1 & 0.41 \\
\hline Sebaceous-cell Carcinoma & 1 & 0.41 \\
\hline Total & 245 & 100.00 \\
\hline
\end{tabular}

Source: Laboratory of Pathology and Cytology Ltd. Aracaju/SE.

Table 2. Distribution of benign neoplasias of salivary glands according to histological type and anatomical site. Aracaju/SE, 2004.

\begin{tabular}{lccccc}
\hline Histological type & $\begin{array}{c}\text { Parotid } \\
(\mathrm{n}-\%)\end{array}$ & $\begin{array}{c}\text { Submandibular } \\
(\mathrm{n}-\%)\end{array}$ & $\begin{array}{c}\text { Salivary Glands } \\
\text { Sublingual } \\
(\mathrm{n}-\%)\end{array}$ & $\begin{array}{c}\text { Minor } \\
(\mathrm{n}-\%)\end{array}$ & $\begin{array}{c}\text { Total } \\
(\mathrm{n}) \%\end{array}$ \\
\hline Pleomorphic Adenoma & $106-86.18$ & $37-97.37$ & $2-100.00$ & $23-95.83$ & $168-89.94$ \\
Warthin's Tumor & $16-13.01$ & $1-2.63$ & - & - & $17-9.09$ \\
Canalicular Adenoma & $1-0.81$ & - & - & $1-4.17$ & $2-1.07$ \\
\hline Total & $123-100.00$ & $38-100.00$ & $2-100.00$ & $24-100.00$ & $187-100.00$ \\
\hline
\end{tabular}

Source: Laboratory of Pathology and Cytology Ltd. Aracaju/SE.

Table 3. Distribution of malignant neoplasias of salivary glands according to histological type and anatomical localization. Aracaju/SE, 2004.

\begin{tabular}{|c|c|c|c|c|c|}
\hline \multirow{2}{*}{ Histological type } & \multicolumn{5}{|c|}{ Salivary Glands } \\
\hline & $\begin{array}{l}\text { Parotid } \\
(\mathrm{n}-\%)\end{array}$ & $\begin{array}{l}\text { Submandibular } \\
\qquad(\mathrm{n}-\%)\end{array}$ & $\begin{array}{l}\text { Sublingual } \\
(\mathrm{n}-\%)\end{array}$ & $\begin{array}{l}\text { Minor } \\
(\mathrm{n}-\%)\end{array}$ & $\begin{array}{l}\text { Total } \\
\text { (n) \% }\end{array}$ \\
\hline Cystic Adenoid Carcinoma & $2-7.14$ & $3-37.50$ & - & $8-36.36$ & $13-22.41$ \\
\hline Acinar-cell Carcinoma & $5-17.86$ & $4-50.00$ & - & $3-13.64$ & $12-20.69$ \\
\hline Mucoepidermoid Carcinoma & $5-17.86$ & - & - & $6-27.27$ & $11-18.97$ \\
\hline Carcinoma in Pleomorphic Adenoma & $8-28.57$ & - & - & $1-4.55$ & $9-15.52$ \\
\hline Adenocarcinoma & $4-14.29$ & $1-12.50$ & - & $4-18.18$ & $9-15.52$ \\
\hline Squamous-cell Carcinoma & $2-7.14$ & - & - & - & $2-3.45$ \\
\hline Salivary Duct Carcinoma & $1-3.57$ & - & - & - & $1-1.72$ \\
\hline Sebaceous-cell Carcinoma & $1-3.57$ & - & - & - & $1-1.72$ \\
\hline Total & $28-100.00$ & $8-100.00$ & - & $22-100.00$ & $58-100.00$ \\
\hline
\end{tabular}

Source: Laboratory of Pathology and Cytology Ltd. Aracaju/SE.

Table 4. Distribution of benign neoplasias of salivary glands according to histological type and gender. Aracaju/SE, 2004.

\begin{tabular}{lccc}
\hline Histological type & Gender & Total $(\mathrm{n}) \%$ \\
\hline Pleomorphic Adenoma & Female $(\mathrm{n}-\%)$ & Male $(\mathrm{n}-\%)$ & $168-89.94$ \\
Warthin's Tumor & $114-97.44$ & $54-77.14$ & $17-9.09$ \\
Canalicular Adenoma & $2-1.71$ & $15-21.43$ & $2-1.07$ \\
\hline Total & $1-0.85$ & $1-1.43$ & $187-100.00$
\end{tabular}

Source: Laboratory of Pathology and Cytology Ltd. Aracaju/SE. 
Table 5. Distribution of malignant neoplasias of salivary glands according to histological type and gender. Aracaju/SE. 2004.

\begin{tabular}{lccc}
\hline Histological type & Gender & Male $(\mathrm{n}-\%)$ & Total $(\mathrm{n}) \%$ \\
\hline Cystic Adenoid Carcinoma & Female $(\mathrm{n}-\%)$ & $4-18.18$ & $13-22.41$ \\
Acinar-cell Carcinoma & $9-25.00$ & $4-18.18$ & $12-20.69$ \\
Mucoepidermoid Carcinoma & $8-22.22$ & $5-22.73$ & $11-18.97$ \\
Carcinoma in Pleomorphic Adenoma & $6-16.67$ & $2-9.09$ & $9-15.52$ \\
Adenocarcinoma & $7-19.44$ & $6-27.27$ & $9-15.52$ \\
Squamous-cell Carcinoma & $3-8.33$ & - & $2-3.45$ \\
Salivary Duct Carcinoma & $2-5.56$ & $1-4.55$ & $1-1.72$ \\
Sebaceous-cell Carcinoma & $1-2.78$ & - & $1-1.72$ \\
\hline Total & $36-100.00$ & $22-100.00$ & $58-100.00$ \\
\hline
\end{tabular}

Fonte: Laboratório de Patologia e Citologia Ltda. Aracaju/SE.

Table 6. Distribution of benign neoplasias of salivary glands according to histological type and age of patients. Aracaju/SE. 2004.

\begin{tabular}{|c|c|c|c|c|c|c|c|c|c|c|c|}
\hline \multirow[t]{3}{*}{ Histological type } & \multicolumn{7}{|c|}{ Age in Decades } & \multirow{3}{*}{$71-80$} & \multirow{3}{*}{$81-90$} & \multirow{2}{*}{\multicolumn{2}{|c|}{ Total }} \\
\hline & \multirow[t]{2}{*}{$1-10$} & \multirow[t]{2}{*}{$11-20$} & \multirow[t]{2}{*}{$21-30$} & \multirow[t]{2}{*}{$31-40$} & \multirow[t]{2}{*}{$41-50$} & \multirow[t]{2}{*}{$51-60$} & \multirow[t]{2}{*}{$61-70$} & & & & \\
\hline & & & & & & & & & & (n) & $\%$ \\
\hline Pleomorphic Adenoma & 2 & 18 & 36 & 28 & 28 & 25 & 15 & 6 & 3 & 161 & 89.94 \\
\hline Warthin's Tumor & - & - & - & - & 2 & 7 & 4 & 2 & 1 & 16 & 8.94 \\
\hline Canalicular Adenoma & - & - & 1 & - & - & 1 & - & - & - & 2 & 1.12 \\
\hline Total & 2 & 18 & 37 & 28 & 30 & 33 & 19 & 8 & 4 & $179 *$ & 100.00 \\
\hline
\end{tabular}

Source: Laboratory of Pathology and Cytology Ltd. Aracaju/SE.

* Patients' ages were not available in 8 cases.

Table 7. Distribution of malignant neoplasias of salivary glands according to histological type and age of patients. Aracaju/SE. 2004.

\begin{tabular}{|c|c|c|c|c|c|c|c|c|c|c|c|}
\hline \multirow[t]{3}{*}{ Histological type } & \multicolumn{9}{|c|}{ Age in Decades } & \multirow{2}{*}{\multicolumn{2}{|c|}{ Total }} \\
\hline & \multirow[t]{2}{*}{$1-10$} & \multirow[t]{2}{*}{$11-20$} & \multirow[t]{2}{*}{$21-30$} & \multirow[t]{2}{*}{$31-40$} & \multirow[t]{2}{*}{$41-50$} & \multirow[t]{2}{*}{$51-60$} & \multirow[t]{2}{*}{$61-70$} & \multirow[t]{2}{*}{$71-80$} & \multirow[t]{2}{*}{$81-90$} & & \\
\hline & & & & & & & & & & (n) & $\%$ \\
\hline Cystic Adenoid Carcinoma & - & - & - & 4 & 1 & 1 & 5 & 2 & - & 13 & 22.81 \\
\hline Acinar-cel Carcinoma & - & - & - & 2 & 2 & 1 & 4 & 2 & 1 & 12 & 21.05 \\
\hline Mucoepidermoid & - & 2 & 1 & 1 & 3 & - & 2 & 2 & - & 11 & 19.30 \\
\hline Carcinoma & & & & & & & & & & & \\
\hline Carcinoma in & - & - & - & 1 & 1 & 3 & 1 & 1 & 2 & 9 & 15.79 \\
\hline Pleomorphic Adenoma & & & & & & & & & & & \\
\hline Adenocarcinoma & - & - & - & 2 & & 2 & 3 & 1 & 1 & 9 & 15.79 \\
\hline Squamous-cell Carcinoma & - & - & - & - & 1 & 1 & - & - & - & 1 & 1.75 \\
\hline Salivary Duct Carcinoma & - & - & - & - & 1 & 1 & - & - & - & 1 & 1.75 \\
\hline Sebaceous-ce Carcinoma & - & - & - & - & - & - & - & - & - & 1 & 1.75 \\
\hline Total & 0 & 2 & 1 & 10 & 8 & 9 & 15 & 8 & 4 & $57 *$ & 100,00 \\
\hline
\end{tabular}

Source: Laboratory of Pathology and Cytology Ltd. Aracaju/SE.

* Patients' ages were not available in 1 case of squamous-cell carcinoma. 
Table 8. Distribution of benign neoplasias of salivary glands according to histological type and race. Aracaju/SE. 2004.

\begin{tabular}{|c|c|c|c|c|c|}
\hline \multirow[t]{2}{*}{ Histological Type } & \multicolumn{3}{|c|}{ Race } & \multicolumn{2}{|c|}{ Total } \\
\hline & Caucasian(n - \%) & Mulato(n-\%) & Black(n - \%) & (n) & $\%$ \\
\hline Pleomorphic Adenoma & $59-92.19$ & $46-92.00$ & $9-90.00$ & 114 & 91.94 \\
\hline Warthin's Tumor & $5-7.81$ & $3-6.00$ & - & 8 & 6.45 \\
\hline Canalicular Adenoma & - & $1-2.00$ & $1-10.00$ & 2 & 1.61 \\
\hline Total & $64-100.00$ & $50-100.00$ & $10-100.00$ & $124 *$ & 100.00 \\
\hline
\end{tabular}

Source: Laboratory of Pathology and Cytology Ltd. Aracaju/SE.

* Patient's race was not available in 63 cases.

Table 9. Distribution of malignant neoplasias of salivary glands according to histological type and race. Aracaju/SE. 2004.

\begin{tabular}{|c|c|c|c|c|c|}
\hline \multirow[t]{2}{*}{ Histological Type } & \multicolumn{3}{|c|}{ Race } & \multicolumn{2}{|c|}{ Total } \\
\hline & Caucasian(n - \%) & Mulato(n - \%) & Black(n - \%) & (n) & $\%$ \\
\hline Cystic Adenoidal Carcinoma & $5-22.73$ & $4-26.67$ & - & 9 & 24.32 \\
\hline Acinar-cells Carcinoma & $5-22.73$ & $3-20.00$ & - & 8 & 21.62 \\
\hline Mucoepidermoid Carcinoma & $4-18.48$ & $3-20.00$ & - & 7 & 18.92 \\
\hline Carcinoma in Pleomorphic Adenoma & $5-22.73$ & $2-13.33$ & - & 7 & 18.92 \\
\hline Adenocarcinoma & $1-4.55$ & $3-20.00$ & - & 4 & 10.81 \\
\hline Squamous Cell Carcinoma & $1-4.55$ & - & - & 1 & 2.70 \\
\hline Salivary Duct Carcinoma & $1-4.55$ & - & - & 1 & 2.70 \\
\hline Sebaceous Cell Carcinoma & - & - & - & - & - \\
\hline Total & $22-100.00$ & $15-100.00$ & & $37^{*}$ & 100.00 \\
\hline
\end{tabular}

Source: Laboratory of Pathology and Cytology Ltd. Aracaju/SE.

* Patient's race was not available in 21 cases.

Out of 245 cases of major and minor epithelial salivary glandular neoplasias, it was observed that major salivary glands were most commonly affected both in benign and malignant neoplasias, specially the parotid gland (61.6\%), which is reported in the majority of the scientific series.

In the present study, submandibular gland represented the second most frequent site of benign and malignant neoplasias, which was also highlighted by other publications ${ }^{13}$. Only 2 cases of sublingual glands were verified, corroborating literature findings that this is the site less affected by these neoplasms.

Benign neoplasias were more frequent in women than in men at a 1.6:1 rate, with mean age of 40.1 years. Malignant neoplasias were also observed with higher frequency in women at a 1.6:1 rate and mean age of 54.8 years. Similar findings were observed in other studies ${ }^{1,8}$.

Peak incidence of benign neoplasias was observed at the third decade of life in the first sample, and at the seventh decade among malignant neoplasias. Some studies 5 showed that for benign lesions, the peak incidence occurred at the sixth decade and, for malignant lesions, at the seventh decade of life, partly corroborating the findings of the present study, except for benign neoplasias.

In this study, benign neoplasias rarely occurred in the first decade of life, except for two cases of pleomorphic adenomas. However, malignant neoplasias were not verified in the first decade of life, while only two cases were diagnosed in the second decade - both of them were mucoepidermoid carcinomas. Studies carried out with children presenting salivary glandular neoplasias and at age below 19 concluded that mucoepidermoid carcinoma was also the most frequent neoplasia found in this age range ${ }^{6}$.

In the present study, predominance of lesions was observed in Caucasians, which is difficult to interpret, taking into account its variable aspect and the country's significant miscegenation. Moreover, there is poor information available on this variable, yielding inconsistent analysis.

Regarding histological types diagnosed in this study, pleomorphic adenoma was the most frequent lesion in the sample (68.57\%), as well as among benign neoplasias (89.94\%), which is in accordance with most published series around the world.

Out of 168 cases of pleomorphic adenoma, 114 (97.44\%) occurred in women, with a peak incidence at the third decade of life and mean age of 40.2 years. Similar studies reported that these lesions predominantly occurred in women with peak incidence at the third decade of life ${ }^{2}$. The most frequent site of pleomorphic adenomas in this study was the parotid gland; however, it is important to emphasize that this neoplasia was also the most frequently found in other salivary glands, which is consistent with other published reports ${ }^{11,13}$. 
Malignant neoplasias of salivary glands summed 58 cases (23.67\%), among which cystic adenoid carcinoma was the majority, totalizing 13 cases (22.41\%). These findings are similar to other publications ${ }^{12}$, although they are different from studies reporting the mucoepidermoid carcinoma as the most frequent malignant neoplasia ${ }^{2,14}$. However, in the present study, two cases represent the difference between the number of cystic adenoid carcinoma and of mucoepidermoid, which is not considered significant when compared to other series.

In summary, the data presented in this study are very similar to those of other published research studies. We concluded that the incidence of salivary glandular neoplasias in the State of Sergipe is in accordance with the incidence observed in several other regions of Brazil and worldwide.

\section{REFERENCES}

1. Loyola AM, Araújo VC, Sousa SO, Araújo NS. Minor salivary gland tumours. A retrospective study of 164 cases in a Brazilian population. Oral Oncol Eur F Câncer 1995; 31B: 197-201.

2. Rivera-Bastidas H, Ocanto RA, Azevedo AM. Intraoral minor salivary gland tumours: a retrospective study of 62 cases in Venezuelan population. J Oral Pathol Med 1996; 25: 1-4.

3. Ellis GL, Auclair PL. Tumours of the Salivary Glands. Atlas of Tumour Pathology, Washington: Armed Forces Institute of Pathology; 1996. p.1-37.
4. Dardick I, Burford-Mason AP, Garlick DS, Carney WP. The pathobiology of salivary gland II. Morphological evaluation of acinic cell carcinomas in the parotid gland of male transgenic (MMTV/v-Ha-ras) mice as a model for human tumours. Virchows Archiv A Pathol Anat 1992; 421: 105-13.

5. Eveson J W, Cawson RA. Salivary gland tumours. A review of 2410 cases with particular reference to histological types, site, age and sex distribution. J Pathol 1985; 14: 51-8.

6. Ribeiro KC, Kowalski LP, Saba LM, Camargo B. Epithelial salivary glands neoplasms in children and adolescents: a forty-four year experience. Med Pediatr Oncol 2002; 39: 594-600.

7. Figueiredo, CRLV, Amaral, RR, Pinho, MMMS, Freitas, JSA, Rolim, MLM, Souza, LB. Estudo epidemiológico de tumores benignos e malignos de glândula salivar - análise de 196 casos em Natal (RN). Rev ABO Nac 2001; 8: 343-8.

8. Ledesma-Montes C, Garces-Ortiz M. Salivary gland tumours in a Mexican sample: a retrospective study. Med Oral 2002; 7: 324-30.

9. Neville BW, Damm DD, Allen CM, Bouquot J. Patologia oral e maxilofacial. 2 ed. Rio de Janeiro: Guanabara Koogan; 2004. p. 301-35.

10. Regezi JA, Sciubba JJ. Patologia bucal: correlações clinicopatológicas. Rio de Janeiro: Guanabara Koogan; 2000. p.213-43.

11. Cantisano MH. Prevalência, parâmetros clínicos e revisão diagnóstica das neoplasias de glândulas salivares na Faculdade de Odontologia de Araçatuba/UNESP. Araçatuba/SP, 1998,. 116p. (Tese de Doutorado em Odontologia - Universidade Estadual Paulista).

12. Kayembe MK, Kalengayi MM. Salivary gland tumours in Congo (Zaire). Odontostomatol Trop 2002; 25: 19-22.

13. Hill AG. Major salivary gland tumours in a rural Kenyan hospital. East Afir Med J 2002; 79: 8-10.

14. Seifert G, Sobin L. The World Health Organization's Histological Classification of salivary gland tumors. A commentary on the second edition. Câncer 1992; 70: 379-85. 